\title{
THE RIGHT TO HOUSING: DURING AND AFTER THE COVID-19 PANDEMIC
}

EL DERECHO A LA VIVIENDA: DURANTE Y DESPUÉS DE LA PANDEMIA DEL COVID-19

\author{
Bohdan Fasii* \\ Andrii Levytskyi ${ }^{* *}$ \\ Andrii Savytskyi ${ }^{* * *}$
}

\begin{abstract}
The importance of ensuring the right to housing during the pandemic Covid-19 and avoiding its negative impact on all spheres of human life is multifaceted. In particular, the least protected sections of the population, who often do not have their housing at all, usually are deprived of the opportunity to follow the rules of social distance and suffer more than others from the disease. Unsatisfactory living conditions during the period of complete quarantine and the need to stay at home all the time, indirectly affect the mental state of people and cause quarrels, domestic violence, and other problems of their residents. The purpose of the study is to establish the constitutive elements of the right to housing as a basic constitutional right, and to find ways of legal foundation of this right. The subject of the study are national and international regulations that ensure the right to housing, decisions of national and international courts, and constitutional doctrine. The research methods were philosophical, general scientific, and special
\end{abstract}

\footnotetext{
* Ph. D., Head of Mykolayiv institute of law, Associate Professor of Civil law Department of National University "Odesa Law Academy" (Mykolayiv, Ukraine). https://orcid.org/0000-0002-8715-930X. fasiy@onua.edu.ua

${ }^{* *}$ Ph. D., Senior Lecturer, Department of Criminal Law and Other Criminal Law Disciplines of Mykolayiv Institute of Law, National University “Odessa Law Academy” (Mykolayiv, Ukraine). https://orcid.org/0000-0003-2266-9250. levichkiy@ukr.net

*** Ph. D. candidate of Intellectual Property and Corporate Law Department of National University "Odesa Law Academy" (Odesa, Ukraine). https://orcid.org/0000-0002-47803789. asavitsk83@gmail.com
} 
scientific methods such as system-structural, comparative and formal methods. As a result of the study, the authors of the article came to the conclusion that the right to housing should be provided both at the level of national and international regulations. Scholars and legislators need special attention to ensuring the housing rights of vulnerable groups. Government subsidies and benefits are key to both the poor affected by the pandemic and businesses that are forced to lose profits.

Keywords: Right to Housing, Pandemic, Constitution, Human Rights, Combating Domestic Violence

Resumen: La importancia de garantizar el derecho a la vivienda durante la pandemia del Covid-19, y de evitar su impacto negativo en diversos aspectos de la vida humana, es multifacética. Los sectores menos protegidos de la población suelen sufrir más por carecer de vivienda y verse privados de la oportunidad de seguir las reglas de la distancia social. Las condiciones de vida insatisfactorias durante la cuarentena completa y la necesidad de permanecer en casa todo el tiempo, afectan indirectamente el estado mental de las personas y causan disputas, violencia doméstica y otros problemas de sus residentes. El propósito del estudio es establecer los elementos constitutivos del derecho a la vivienda como un derecho constitucional básico y encontrar formas de sustento legal de este derecho. El tema del estudio son las normativas nacionales e internacionales que garantizan el derecho a la vivienda, decisiones de tribunales nacionales e internacionales y doctrina constitucional. Los métodos de investigación fueron filosóficos, científicos generales y métodos científicos especiales como sistémicoestructural, comparativo y formal. Como resultado del estudio, los autores del artículo llegaron a la conclusión de que el derecho a la vivienda debe proporcionarse tanto a nivel nacional como internacional. Los académicos y legisladores necesitan dedicar especial atención para garantizar los derechos a la vivienda de los grupos vulnerables. Los subsidios y beneficios del gobierno son clave tanto para los pobres afectados por la pandemia, como para las empresas que se ven obligadas a perder ganancias.

Palabras clave: Derecho a la vivienda, pandemia, constitución, derechos humanos, lucha contra la violencia doméstica

Summary. I. Introduction. II. Analysis of recent research. III. Results and discussion. III.1. The Current State of the Problem of Ensuring the Right to Housing in the World. III.2. International Experience of the Ensuring the Right to Housing. IV. Conclusions. References. 


\section{INTRODUCTION}

The call to stay at home, along with the requirement to wear a mask, wash your hands, and maintain social distance, has become the main slogan of the fight against the new coronavirus epidemic. However, when it comes to solving practical problems related to housing (its affordability, ability to maintain a proper financial condition for renting it, etc.) become important conditions for compliance with quarantine measures. During the lockdown, housing has a decisive influence on the ability to work, exercise the right to education, raise children, and provide care, custody, mental health, and safety.

It is known that housing is one of the basic human needs. The guarantee of the right to housing is contained in the main normative acts of both international and national law. In particular, such formulations can be found in the Universal Declaration of Human Rights (1948, Article 25) and the Constitution of Ukraine (Articles 47, 48). The International Covenant on Economic, Social and Cultural Rights (1966) obliges States parties to take all measures to ensure the realization of the right of everyone to an adequate standard of living for himself and his family, including adequate food, clothing, and housing, as well as improving life (Article 11). Universal access to adequate, safe, and affordable housing is among the Sustainable Development Goals (Goal 11) proclaimed by United Nations General Assembly Resolution $n^{\circ}$ 70/1 of September 25, 2015.

This publication is designed to analyze the current international experience in the implementation of the right to housing in the pandemic Covid-19, the national legislation of Ukraine in this aspect, as well as to outline a possible framework for further development on the topic.

\section{ANALYSIS OF RECENT RESEARCH}

Hartman (1998) once proposed a discussion of the very concept of the right to housing, describing the facts that indicate the socio-cultural conditionality of this phenomenon. The authors' conclusion is mainly a critical look at the economic and cultural determinants of American society, in which social rights issues are given, in his opinion, insufficient attention or such topics are ignored altogether. However, the researcher's publication has become a starting point for more detailed research on the topic.

Bengtsson (2001), for his part, made a demarcation between the universal and selective application of the right to housing in the context of the welfare state and the degree of its intervention in the economy to ensure 
equitable access to housing for the poor or vulnerable. According to this approach, selective intervention does not fully affect the market, helping the most vulnerable households to equalize their financial position. In the universal model, the state claims to fully fulfill its duty to citizens and provide everyone with affordable housing.

Bratt, Stone, and Hartman (2006) in their textbook provided a comprehensive overview of what they believe is and could potentially be the right to housing. Emphasis is placed on the social role of this concept and the prospects of its place in the modernized social system.

Adams (2008) critically approached the very basics of formulating the concept of the right to housing, analyzing its two components: what is the right (from a philosophical, sociological, political, legal point of view) and what is meant by housing, but a more accurate translation of the author's understanding approaches the concept of the right to housing as a set of measures to provide affordable housing, adequate, comfortable living and socialization for the broad, particularly vulnerable, segments of the population.

Hohmann (2013) interprets the right to housing through the prism of natural law and human rights. For him, the right to affordable housing, or simply the right to housing - is a complex phenomenon, which is characterized by both social and economic, as well as cultural components. But the main thing for him is that it is inherent in every person by nature simply because man is a man. Thus, the right to housing as a component of other human rights is rightly mentioned among other powers in such international legal acts as the Universal Declaration of Human Rights and the International Covenant on Economic, Social, Cultural Rights, and should be universal, cross-border in nature.

Kravchenko and Cheberyak (2017) investigated the genesis of the right to housing in Ukrainian legislation. The authors conclude that there are obstacles or gaps in Ukrainian legislation that have formed as a result of the convergence of different legal systems (Western and Eastern, liberal and authoritarian, capitalist and socialist, etc.), which negatively affected the development of housing law in Ukraine in general and the institution of the right to housing in particular. Outdated norms of the Housing Code of the Ukrainian Soviet Socialist Republic (1983) from this point of view can be considered as rudimentary entities that need to be adapted to modern market conditions (respect for property rights, human rights, and freedoms, the rule of law).

The issue of the legal nature of the right to housing, the characteristics of its constitutional status (Veschunova, 2017; Skripko, 2002) is becoming increasingly important in scientific circles. 
The lack of thorough development of the theoretical and legal framework for the concept of the right to housing leads to gaps in the legislation, which are primarily related to the framework provisions of housing law. Not taking into account its existence at the institutional level, it is a difficult task to build a truly fair and far-sighted legal regulation in this area (Bogdanov, 2003).

As Pchelintseva (2004) points out, at the scientific level, namely in the theory of housing law, there is still no consensus on what exactly is meant by the right to housing.

There is a view that the right to housing is considered in the context of civil law, and in this case acquires a more detailed name, namely the right to housing. In this case, its legal nature is assessed by scholars as a social right, i.e., permissible behavior aimed at ensuring and protecting the interests and needs of citizens (Veschunova, 2017).

An important role in this aspect is played by the national housing strategy as a set of actions, decisions, methods, ways and means of influencing and achieving the goals of the state in the field of housing law. In turn, the housing strategy, as the right to housing is social, is part of a wider range of social policies. The realization of the right to housing is one of the main tasks of the state, which is recognized at the international level.

The right to housing is not isolated from other types of permissible behavior in its legal nature, and therefore, as a subjective right is constructed on a par with others, which creates a set of powers that is realized in the form of subjective right for housing. Thus, its maintenance is specified in process of its realization (conditions, the order of use, and other aspects).

It is necessary to cite in this context the scientific achievements of Sedugin (2003), who proposed to consider the right to housing as a multifaceted, complex concept. In this regard, he identified six legal opportunities provided to the subject of the right to housing. These include: (i) stable use of occupied housing in buildings of state, municipal, and other housing stock; (ii) improvement of living conditions, obtaining other living space by various legal methods; (iii) disposal of residential premises (lease, rental, etc.); (iv) adequate living conditions; (v) inadmissibility of arbitrary deprivation of citizens of the right to housing; and (vi) constitutional and legal connection with the inviolability of the home, protection against the intrusion of other persons against the will of those living in it, inviolability of private life, the right to judicial protection, etc. For Sedugin (2003), the right to housing by its legal nature is a state-legal institution, belongs to everyone from birth, and is inalienable, as it belongs to the basic constitutional rights of citizens. 
Kachalova (2006) in his work adheres to the distinction between the concepts of "right to have housing" and "right to housing" In the first case, we have the right of ownership as an integral part of the legal capacity, and in the second, the right to own/dispose/use a specific premises. This point of view argues that the right to housing is a component of the general legal capacity of an individual, and the right to housing is a civil right to a specific object of residential real estate. From this, the researcher concludes the threefold legal nature of such a right, according to which it can be real, binding, or corporate.

According to Davletova (2003) compares the subjective civil right to housing with the realized constitutional right to housing. Thus, the constitutional right to housing is only a subjective right to the possibility of owning housing, enshrined in the Constitutions of different countries, and serves as a normative basis for the emergence of a subjective civil right to housing.

Davletova (2003), taking into account the general idea of the concept of "subjective right" under the subjective civil right to housing means «the type and extent of possible behavior of the authorized person, which (behavior) consists of housing belonging to this person on one or another legal basis» (p. 18).

Thus, Article 47 of the Constitution of Ukraine establishes three means of exercising the right of citizens to housing: (i) the ability to build housing; (ii) to acquire property; and (iii) rent.

Besides, for certain segments of the population, which are recognized in the manner prescribed by law as in need of social protection, the Constitution establishes two means of exercising the right to housing: receiving free of charge or for a fee available to them.

Thus, in the narrow sense (civil aspect), the right of citizens to housing can be considered as the right to a specific, already available to a person, and the inadmissibility of his arbitrary deprivation.

In a broad sense (constitutional and legal aspect), the right of citizens to housing - belongs to everyone from birth inalienable right, which includes guaranteed by the state: (i) the ability to be provided with housing, suitable for permanent residence; (ii) the ability to meet housing needs; (iii) the right to inviolability of the home and the inadmissibility of its arbitrary deprivation; (iv) the right to housing security; (v) the right to free movement, choice of place of residence and stay; and (vi) the right to the unimpeded exercise of housing rights due to a citizen (Sotnikova, 2006).

Despite the fact that many issues related to the right to housing during the pandemic have been the subject of research by domestic and foreign researchers, some problematic aspects of ensuring the right to housing 
remain unattended by scientists. In particular, it concerns the right to housing of foreigners, stateless persons, and migrants who are in a certain territory temporarily.

\section{RESULTS AND DISCUSSION}

\section{III.1. The Current State of the Problem of Ensuring the Right to Housing in the World}

Global epidemics can pose both short-term and long-term consequences for the economic environment (Jordà, Singh \& Taylor, 2020). This statement is also true for the Covid-19 pandemic. It is possible to trace its systematic influence at different levels, in different branches, dimensions, spheres of life. Deteriorating conditions of economic activity affect the implementation of social programs and human rights. One of the litmus tests of the state of economic development, which is related to housing law, is the real estate market. The epidemic affects it in a way that significantly reduces the demand for living space, which is located in densely populated areas (Liu $\& \mathrm{Su}, 2020)$. The fear factor of coronavirus infection forces people to seek accommodation outside modern cities (Autor \& Reynolds, 2020). Also, employees have switched to teleworking (Bartik, Cullen, Glaeser, Luca \& Stanton, 2020; Mas \& Pallais, 2020; Bick, Blandin \& Mertens, 2020), as this form of doing business is now preferred.

The service sector suffers from quarantine catastrophically. Under the influence of the danger of infection inside restaurants and cafes, their owners began to suffer significant losses, staff began to suffer from salary cuts and job losses (Allcott et al., 2020; Chen, Qian \& Wen, 2020; Chetty, Friedman, Hendren, Stepner \& the Opportunity Insights Team, 2020; Cox et al., 2020).

The practice has shown that the restrictions have been long-lasting, increasing, or decreasing under the influence of the situation with the spread of coronavirus. Therefore, we can say that the hopes of those people who thought that the world would soon return to the previous conditions of existence, did not come true. Thus, the effect of reducing the attractiveness of urban real estate in densely populated areas also proved to be longer than expected (Liu \& Su, 2020).

Thoughts that Covid-19 allegedly became a kind of equalizer between rich and poor did not come true. The obtained empirical data show that, for example, in Italy, the disadvantaged strata living in densely populated areas have suffered severe consequences of the lockdown (Bonaccorsi et al., 2020). Information on racial and ethnic minorities in the United States shows similar dynamics (Garg, 2020). 
Municipalities are mainly faced with the challenge of protecting local people, and at the national level, governments are faced with the task of developing a national strategy to combat Covid-19 and the effects of the epidemic (Dallas \& Power, 2020). Problems with rent, mortgage lending, utilities, etc. have become particularly acute for vulnerable groups who are at risk of eviction and living below the poverty line.

As a result of quarantine measures, a large number of people found themselves alone with their roommates. The number of cases of domestic violence is increasing (Taub, 2020). For example, in the United Kingdom, the number of hotline calls for victims of domestic violence has been reported to have increased by $25 \%$ since the beginning of the lockdown, and one day in April, the jump in complaints reached $700 \%$ (Townsend, 2020). In Ukraine, in the first ten months of 2020, the police received 174,386 reports of domestic violence, and 3,124 complaints were made by children (Roshchyna, 2020). In the previous year, this number was 113,763 and 1,517 messages, respectively. Even though the National Police (2020) explained such statistics by an increase in trust in law enforcement agencies, research by foreign scientists (Bradbury-Jones \& Isham, 2020; Peterman et al., 2020), citizens of those countries that are currently in a more developed situation in terms of combating domestic violence, indicate that the pandemic has become a trigger for an increase in cases of abuse. It is also worth noting that in Ukraine 7 regions still do not have shelters for victims of domestic violence (Ukrinform, 2020). Once in a confined space, victims need to have a shelter to which they can turn in the event of a threat to their lives or the safety of their loved ones (Campbell, 2020). However, because shelters are not always sufficient and the increase in the number of victims of domestic violence that may be present may lead to an increase in the incidence of coronavirus (Van Gelder et al., 2020), the lack of adequate policies to combat domestic violence during pandemics and providing victims of abuse with adequate housing are another important problem in the context of coronary crisis (Usher, Bhullar, Durkin, Gyamfi \& Jackson, 2020).

In a comment to Amnesty International in Spain (2020), the organization draws attention to vulnerable groups. According to the WHO (2020), these include the elderly and those with chronic diseases (asthma, diabetes, cardiovascular disease, etc.). They are particularly vulnerable to coronavirus infection and carry it mainly in severe form. With this in mind, states must do everything possible to prevent the undesirable outcome of the disease (Amnesty International in Spain, 2020). Vulnerable groups such as those living below the poverty line can also be identified; people who have limited access to preventive measures (masks, disinfection); migrants without permanent status; people with low income and unprotected 
employment; people without proper access to water and hygiene. In this regard, the governments of all countries need to ensure non-discriminatory access to prevention, treatment, and adequate living conditions, one of which is the right to housing, for all, in particular, these vulnerable groups.

Another problem is the increase in the number of homeless people affected by the negative effects of the coronavirus pandemic (Lima et al., 2020; Perri, Dosani \& Hwang, 2020). Due to job loss, the general deterioration of the economic situation, people are at risk of being left homeless (Wheelock, 2020). According to Deutsche Welle (2020), this trend is becoming particularly noticeable in the United States. According to an Associated Press report (2020), as of July 2020, 153 deaths due to coronavirus infection were recorded among homeless people in metropolitan areas such as San Francisco, Los Angeles, New York, Washington, DC, Phoenix and Seattle, and in early August 206 deaths.

The economic interests of tenants and landlords are also in question, as the problem cannot be resolved in favor of just one party. Thus, it is necessary to take into account that it was convenient for tenants to rent housing with livelihoods, and landlords did not suffer from lost profits due to the emergency of the pandemic. One way or another, foreign experience shows that one way to respect the right of individuals to housing is to impose a ban on evictions by landlords for the duration of the lockdown (Benfer $e t$ al., 2020; Leifheit et al., 2020). Besides, there are housing voucher programs, subsidizing tenants and landlords so that they do not lose part of their income under the influence of circumstances beyond their control. However, it is clear that this is a serious economic problem that requires sound political and legal settlement to respect the rights of stakeholders, and objective obstacles only make it difficult to make the only optimal solution.

During a pandemic, when family incomes are declining, the opportunity to save on utilities is especially important. In particular, one of the ways to save on the services of service companies and private managers, without reducing the overall quality of utilities, is the organization of condominiums. This form of housing management allows residents of an apartment building to independently perform some of the functions performed by external companies. Accordingly, proper legal regulation of relations with the participation of condominiums should become one of the priorities of legislative activity.

Thus, as we can see, the problem of housing affordability and related issues exacerbate the situation around the coronavirus epidemic. The thematic blocks of unresolved issues are reflected in the increase in the number of homeless people, cases of domestic violence, economic difficulties, and financial difficulties of landlords, tenants, and homeowners. 


\section{III.2 Current International Legislation and Areas of Work}

The legal basis for the right to housing appears stated in the following basic international human rights provisions:

The Universal Declaration of Human Rights (1948), Article 25.1. «Everyone has the right to a standard of living adequate for the health and well-being of himself and of his family, including food, clothing, housing and medical care and necessary social services, and the right to security in the event of unemployment, sickness, disability, widowhood, old age or other lack of livelihood in circumstances beyond his control.»

Convention relating to the Status of Refugees (1951), Article 21. «As regards housing, the Contracting States, in so far as the matter is regulated by laws or regulations or is subject to the control of public authorities, shall accord to refugees lawfully staying in their territory treatment as favourable as possible and, in any event, not less favourable than that accorded to aliens generally in the same circumstances.»

Convention on the Elimination of all Forms of Racial Discrimination (1965), Article 5 (e) (iii) [obliges States] «to prohibit and to eliminate racial discrimination in all its forms and to guarantee the right of everyone, without distinction as to race, colour, or national or ethnic origin concerning the right to housing».

International Covenant on Economic, Social and Cultural Rights (ICESCR) (1966), Article 11.1. «The States Parties to the present Covenant recognize the right of everyone to an adequate standard of living for himself and his family, including adequate food, clothing and housing, and to the continuous improvement of living conditions. The States Parties will take appropriate steps to ensure the realization of this right, recognizing to this effect the essential importance of international cooperation based on free consent.»

The report of the Special Rapporteur on Adequate Housing (2019) and the United Nations Human Settlements Program (UN-Habitat) (2015) can be attributed to the modern profile documents of the international level, clarifying and revealing the above-mentioned articles. Thus, the report for 2014 describes the main areas of work that states should be guided by, taking into account the above problems and the sustainable development program proclaimed by resolution $\mathrm{n}^{\circ} 70 / 1$ of the United Nations General Assembly of September 25, 2015:

(i) Legal guarantee of ownership. All individuals should have some degree of security of private property that guarantees legal protection against forced evictions, harassment, and other threats. Consequently, governments should take immediate action to provide legal guarantees of tenure for households that do not have them. 
(ii) Availability of services, materials and infrastructure. All beneficiaries of the right to housing must have sustainable access to natural and shared resources: clean drinking water, energy for cooking, heating and lighting, sanitation and washing facilities, food storage facilities, garbage disposal, site drainage, and emergency services.

(iii) Affordable Housing. Personal or household expenses related to housing must be such that they do not jeopardize or threaten other basic needs. Housing subsidies must be made available to those unable to obtain affordable housing, and renters must be protected from unnecessary rent increases. Action plans need to be developed, including public expenditure on housing for the poor and housing subsidies, prioritizing the most vulnerable groups such as persons with disabilities, the elderly, minorities, indigenous peoples, refugees, and internally displaced persons, and especially women from these groups. In societies where natural materials are the main building materials for housing, authorities should take steps to ensure the availability of such materials.

(iv) Safe housing. To be adequate, housing must provide residents with enough space and protect them from cold, dampness, heat, rain, wind, and other health threats, structural hazards, and disease vectors. The physical safety of people must be guaranteed.

(v) Accessibility to unprotected groups. Housing should be affordable for everyone, regardless of social status and physical disabilities. Accordingly, groups such as the elderly, children, people with disabilities, terminally ill, HIV-positive people, people with chronic health problems, the mentally ill, victims of natural disasters, and people living in areas prone to natural disasters should be given priority on housing. Housing legislation and policies must take into account the special housing needs of these and other vulnerable groups.

(vi) Appropriate place. To be suitable, housing must be located in such a way as to provide access to work, health care, schools, childcare, and other social facilities. It cannot be built on contaminated sites or near sources of pollution that could violate the residents' right to health.

(vii) Culturally acceptable housing. Housing construction, building materials used and basic policies must preserve cultural identity and diversity. The cultural aspects of housing should not be sacrificed to facilitate housing projects or retrofits.

The list of these broad rights highlights some of the complexities of the right to adequate housing and reveals many areas that a state must consider when fulfilling its legal obligation to meet the housing needs of its population. Any person, family, household, group, or community living 
below these levels of rights can reasonably claim that they do not enjoy the right to adequate housing as enshrined in international human rights law.

Thus, as we can see, today international legislation is quite well developed and there are more questions regarding the implementation by States of their obligations in this area.

\section{III.2. International Experience of the Ensuring the Right to Housing}

Government objectives for realizing the right to housing and their results are extremely diverse by region and country, and detailed information on the general private situation is not difficult to find in the annual reports of the UN and governments. Three precedents give us an idea of the issues that people have in this matter:

(i) Hungary and the criminalization of homelessness. Hungarian legislation, passed in 2010-2011, criminalizes sleeping and performing other life-sustaining activities in public places as an offense punishable by imprisonment or a fine. The legislation gave local authorities the power to confiscate the property of persons without permanent residence and send them to special "concentration centers". The legislation has potentially affected more than 30,000 homeless people in various municipalities in Hungary. In December 2012, the Constitutional Court overturned this law, finding it contrary to the constitutional requirements for legal certainty and protection of the right to human dignity and property rights. Commenting on this decision, the UN Special Rapporteur on Extreme Poverty and Human Rights stressed that it rightly underlines the fact that homelessness is a social problem that needs to be addressed through the provision of adequate services. Unfortunately, the government chose to ignore the decision of the Constitutional Court, passing a constitutional amendment and a new law in 2018 that still allows for the criminalization of the homeless (Delfinov, 2018).

(ii) Kenyan High Court in illegal eviction case. By a November 2011 ruling, the Kenyan High Court granted a petition of over 1,000 people (Constitutional Petition $n^{\circ} 2$ of 2011, Garissa) who were forcibly evicted from their homes, and their homes were demolished by local authorities.

In its ruling, the High Court recognized the interdependence of civil, political, economic, and social rights. He stressed that under the new constitution, ratified international treaties are part of Kenyan law and therefore base their decision on the International Covenant on Civil and Political Rights (ICCPR) (1966) and ICESCR. The court concluded that the state violated the right to adequate housing, water, and sanitation, to physical and mental health, education, information, and fair administrative decisions. 
The court issued a permanent injunction obliging the state to return citizens their land and renovate their homes and/or provide alternative housing. In compensation, the court awarded each of the applicants KSh 200,000 (approximately USD 2,000 at the time). The ruling was seen as setting an important regulatory precedent and breaking new ground by ordering the restoration of destroyed houses and imposing penalties.

(iii) Constitutional Court of South Africa in Government of the Republic of South Africa and Others v. Grootboom and Others (2000). Ms. Grootboom and others, evicted from private property and living on the edge of a sports field in dire conditions, sued for immediate assistance when their temporary shelter became uninhabitable due to the winter rains. The Court ruled that despite the existence of current comprehensive housing legislation and policies aimed at progressively realizing the right to adequate housing, they did not take into account the situation of people in desperate need.

The court applied the criterion of reasonableness to housing policy and found it insufficient: a reasonable portion of the national housing budget was not allocated to people who were desperate for the needy. Although the Court has found that the state is not obliged to provide housing immediately upon request, it still ruled that the state should provide assistance to those who desperately need it as soon as possible.

From the current precedents, we can conclude that the highest court in different countries, guided by constitutions and international law, takes the side of disadvantaged people whose right to housing is violated. Ultimately, however, only the government has real opportunities to help citizens or, on the contrary, persecute them for homelessness.

From modern examples of government policy, in a pandemic, you can draw attention to the experience of the United States, namely-how they address the problem of the impact of the Covid-19 pandemic on housing affordability. On March 25, 2020, the US Senate passed the Coronavirus Aid, Relief and Economic Security Act, which provided for the allocation of a package of social and economic assistance to various groups of the US totaling USD 2.2 trillion (Hulse \& Cochrane, 2020; Snell, 2020; Taylor, Fram, Kellman \& Superville, 2020). Two days later, the document was approved by the House of Representatives and signed by the President (Cochrane \& Stolberg, 2020; Pramuk, 2020). This was the largest legislative event in the country's history (Wire, 2020). Sections 4022 and 4023 of the Act provide rules for the legal regulation of mortgage issues during the Covid-19 pandemic. According to them, protection is provided to entities that have a federally secured mortgage (Consumer Financial Protection Bureau, 2020a). This includes any loan secured by primary or secondary collateral for residential real estate, including individual units of 
condominiums and cooperatives, which is designed mainly for 1 to 4 families (see ref.). It also provided for protection against foreclosure until at least 31 August 2020 (Consumer Financial Protection Bureau, 2020a). Besides, the Act provided for the possibility of deferral of credit payments up to and including 180 days. Section 4024 (b) provides for a 120-day moratorium (from the date of signing of the Act by the President of the United States (March 27, 2020) and until July 24) on applications for eviction from leased units in a property that participates in federal assistance programs or is located under a federal guarantee (Consumer Financial Protection Bureau, 2020b; US Department of Housing and Urban Development, 2020). Also, if a landlord receives assistance under the MultiApartment Mortgage Payments Act, protection against eviction is provided for a longer period of time (Consumer Financial Protection Bureau, 2020b; McCarty \& Carpenter, 2020). According to some estimates, the moratorium covered $28 \%$ of all rented housing in the United States (Goodman, Kaul \& Neal, 2020).

In turn, the US state of California has the Tenant, Homeowner, and Small Landlord Relief and Stabilization Act of 2020, which provides landlords and tenants with a package of opportunities that could help overcome the economic and social hardships caused by the coronavirus epidemic. For example, this document protects tenants who have experienced financial difficulties due to coronavirus in the period from March 4 to August 31, 2020, from September 1, 2020, to January 31, 2021, and pay at least $25 \%$ of the rent, from eviction to February 1, 2021, and also provides some rent benefits. A prerequisite for their use is a justification of the circumstances, which the lessee must indicate in the relevant document (declaration/statement of financial difficulties), which he sends to the address of the landlord. It should be borne in mind that all financial documentation must be available to prove the causal link between the pandemic and the predicament, as it is the Covid-19 epidemic that must be the cause of financial difficulties as an insurmountable force, force majeure if the tenant plans to exercise his right to housing benefits under this act. Covid-19 is not in itself a ground for exemption or reduction of rent. In addition, the tenant is required to pay at least $25 \%$ of the monthly rent for rent in any case.

It should also be noted that, despite the ban on eviction under the influence of coronavirus until February 1, 2021, landlords retain the right to demand payment of arrears for accommodation. However, for violating the eviction procedure, increased liability was introduced for them.

For homeowners and small landlords, protection is provided against foreclosure on a mortgage if it is secured at the level of federal law, 
following the Act passed by Congress. For a federally unsecured mortgage, mortgagors will need to negotiate a reduction or deferral of the loan payments with the mortgagee, who, in the event of a refusal, provides the mortgagor with a justification for the circumstances under which the waiver was made. Homeless people and their families can get a room in a motel/hotel by contacting the relevant social services for help. Agricultural sector workers, grocery store staff, homeless and Covid-19 caregivers, and health care workers are guaranteed housing for the quarantine period if they request social services if necessary.

Homelessness is called almost the most severe form of violation of the right to affordable housing (US Department of Housing and Urban Development, 2015). In the conditions of the Covid-19 pandemic, living in the open air is especially dangerous for the life and health of both the homeless person and others. According to a report by Amnesty International (2020), a number of countries have taken prompt action to address this particular issue. In Portugal, for example, the government has allocated $€$ 7.5 million to the National Fund for Urgent Housing, which has been allocated to social programs to combat domestic violence, combats homelessness, and preserves housing.

Indonesian authorities have decided to place homeless people in gyms and spacious halls (Hamdi, 2020; Kompas, 2020).

On March 28, 2020, in Italy, the Ministry of Labor and Social Policy issued an order regarding the management of the social services system during the Covid-19 emergency. According to this document, it was recommended to create canteens, places to sleep, and distribution points for the homeless. Local and regional authorities were also invited to coordinate their actions between public services and the private sector. However, in the future, the situation with the implementation of this legal act was ambiguous, as the effectiveness of its application in the country as a whole was heterogeneous, which gave rise to criticism of government actions by some NGOs, such as "Avvocato di Strada" (Belardelli, 2020; CSV EmiliaDarVoce, 2020).

Russia's measures in the context of the pandemic in the field of the right to housing also became interesting. So directly related to the right to housing can be noted: (i) preferential mortgage at a rate of $6.5 \%$ (before the pandemic, the average rate was about 10\%); (ii) subsidies for payment of housing and communal services for all citizens; (iii) postponement of renting state, municipal and social housing; and (iv) meeting of homeowners in electronic form, interaction with government agencies through a single portal of government services. 
By not giving money directly to citizens and not paying in full for any services and goods, the Russian government nevertheless eased the situation of the population in this matter, and some measures, such as preferential mortgages, provoked a boom in construction, purchases, and repairs of housing. Because many companies are involved in the construction and related spheres, these events managed not only to support the employment of the population and the financial position of companies but also to address the issue of renovating the housing stock at an accelerated pace (Russian Government official website, 2020).

As a kind of generalization of the practice of different countries Amnesty International (2020b) provides the following list of recommendations for an improved response to Covid-19 in terms of legal regulation and possible measures sanctioned by government institutions in the presence of political will:

(i) In implementing budget allocations, governments should ensure that funds are distributed evenly and appropriately to ensure a nondiscriminatory approach and maximum effectiveness in responding to Covid-19.

(ii) The practice of forced evictions during the Covid-19 pandemic should be limited, as it could violate human rights (the right to housing) and lead to even more negative consequences, including the spread of the disease by the forcibly evicted person, up to fatalities.

(iii) Foreign citizens deserve equal treatment in this aspect.

(iv) It is necessary to take into account the interests of landlords and introduce, as far as possible, tax rebates/deferrals on credit obligations, etc., taking into account the financial situation of each person (this requires a detailed examination of applications for subsidies/financial assistance/discounts, etc. to prevent fraud and illegal redistribution of funds or its improper, non-targeted use).

(v) Attention should be paid to equipping sanitary areas for people living in informal settlements, with the possibility of designing them in a way that minimizes the spread of acute respiratory infections when using sanitary equipment by several persons within a radius of social distance.

(vi) Law enforcement agencies should refrain from punishing homeless people as an excessive and ineffective measure in the context of the Covid19 pandemic.

(vii) Sustainable social development should be based on ensuring the access of vulnerable social groups such as the elderly, the temporarily unemployed, people with disabilities, national minorities, etc. to social support, protection, and security programs (in general) and in times of corona-crisis (in particular). 


\section{CONCLUSIONS}

1. The right to housing is an inalienable basic right of every person, guaranteed by international law. In the scientific community, there are many approaches to understanding certain aspects of this right, but ultimately their differences lie in the legal intricacies of organizing the legislative framework for the implementation of the right to housing as such.

2. Despite the gradually improving situation with the realization of the right to housing, some problematic aspects of securing the right to housing remain ignored by scientists and the public. In particular, this applies to the right to housing of foreigners, stateless persons, and migrants temporarily staying in a certain territory.

3. International law in general fulfills its role as a reference point for national legal systems and the work of governments.

4. Implementation of rights and programs in practice remains problematic, since governments may simply ignore this problem, lack the means and opportunities to implement it, or even fight the consequences of homeless people, and not the reasons why they are homeless. In this context, not only international cooperation is important, but also the activities of citizens. Scientists and public activists should draw attention to this problem in their countries at the local level, taking into account the national specifics, to achieve better results.

5. The pandemic, of course, exacerbated the problem of the right to housing, but at this point there is already the experience of various countries and comprehensive recommendations from international organizations to overcome this crisis, including in terms of housing, and this has become more of a matter of political will. 


\section{REFERENCES}

Adams, K. (2008). Do We Need a Right to Housing? Nevada Law Journal, 9, 275-324. In https://scholars.law.unlv.edu/cgi/viewcontent.cgi?article $=1088 \&$ context $=$ nlj.

Allcott, H., Boxell, L., Conway, J., Ferguson, B., Gentzkow, M. \& Goldman, B. (2020). Economic and health impacts of social distancing policies during the Coronavirus pandemic. Working Paper. https://dx.doi.org/10.2139/ssrn.3610422.

Amnesty International (2020a). Human rights in the context of the Covid-19 pandemic (guide). In https://www.amnesty.org.ua/covid19-hr-guidance/.

Amnesty International. (2020b). Covid-19 and the right to housing. Submission to the UN Special Rapporteur on adequate housing. In https://www.amnesty.org/download/Documents/IOR4026262020ENGLISH.PD F.

Associated Press. (August 24, 2020). Covid-19 is 'a crisis within a crisis' for homeless people. In https://www.modernhealthcare.com/safety-quality/covid-19-crisiswithin-crisis-homeless-people.

Autor, D. \& Reynolds, E. (July 16, 2020). The nature of work after the Covid crisis: Too few low-wage jobs. Brookings. In https://www.brookings.edu/research/thenature-of-work-after-the-covid-crisis-too-few-low-wage-jobs/.

Bartik, A., Cullen, Z., Glaeser, E., Luca, M. \& Stanton, C. (2020). What jobs are being done at home during the Covid-19 crisis? Evidence from firm-level surveys. Harvard Business School Working Paper, 20, 138-145. https://dx.doi.org/10.2139/ssrn.3574741.

Belardelli, J. (April 6, 2020). È fuori casa, perché “vivo per strada". Senzatetto multato a Roma. The Huffington Post Italy. In https://www.huffingtonpost.it/entry/multesenza-fissa-dimora_it_5e8b1d43c5b6e7d76c674726?fbclid=IwAR1b7jz2PJXpAQbqwwkIlw2-5lkXDINBbYiUoRdJJxu7J8UIUtPsj8ciRU.

Benfer, E., Vlahov, D., Long, M., Walker-Wells, E., Pottenger, J., Gonsalves, G. \& Keene, D. (2020). Eviction, Health Inequity, and the Spread of Covid-19: Housing Policy as a Primary Pandemic Mitigation Strategy. Journal of Urban Health, 1, 1-24. In https://ssrn.com/abstract=3736457.

Bengtsson, B. (2001). Housing as a Social Right: Implications for Welfare State Theory. Scandinavian Political Studies, 24, 255-275. In https://doi.org/10.1111/14679477.00056.

Bick, A., Blandin, A. \& Mertens, K. (2020). Work from home after the Covid-19 outbreak. Federal Reserve Bank of Dallas Working Paper 2017. DOI: In https://doi.org/10.24149/wp2017.

Bogdanov, E. V. (2003). The nature and essence of the right of citizens to housing. Journal of Russian Law, 4, 21-29. In https://esj.pnzgu.ru/files/esj.pnzgu.ru/veshchunova_ev_17_3_20.pdf. 
Bonaccorsi, G., Pierri, F., Cinelli, M., Porcelli, F., Galeazzi, A., Flori, A., Schmidth, A.L., Valensise, C.M., Scala, A., Quattrociocchi, W. \& Pammolli, F. (2020).

Economic and Social Consequences of Human Mobility Restrictions under Covid-19 (April 11, 2020). Proceedings of the National Academy of Sciences, 6, 1-38. DOI: 10.1073/pnas.2007658117. In https://ssrn.com/abstract=3573609.

Bradbury-Jones, C. \& Isham, L. (2020). The pandemic paradox: The consequences of COVID-19 on domestic violence. Journal of clinical nursing, 1, 2047-2049. DOI: $10.1111 /$ jocn.15296. In https://onlinelibrary.wiley.com/doi/pdf/10.1111/jocn.15296.

Bratt, R., Stone, M. \& Hartman, C. (Eds.). (2006). A right to housing: Foundation for a new social agenda. Philadelphia: Temple University Press.

Campbell, A. (2020). An increasing risk of family violence during the Covid-19 pandemic: Strengthening community collaborations to save lives. Forensic Science International: Reports, 100089. In https://www.sciencedirect.com/science/article/pii/S2665910720300384.

Chen, H., Qian, W. \& Wen, Q. (2020). The impact of the Covid-19 pandemic on consumption: Learning from high frequency transaction data. Working paper. DOI: In https://dx.doi.org/10.2139/ssrn.3568574.

Chetty, R., Friedman, J., Hendren, N., Stepner, M. \& the Opportunity Insights Team. (2020). How did Covid-19 and stabilization policies affect spending and employment? A new real-time economic tracker based on private sector data. Working Paper. https://doi.org/10.3386/w27431.

Cochrane, E. \& Stolberg, S. (March 27, 2020). \$2 Trillion Coronavirus Stimulus Bill Is Signed Into Law. The New York Times. In https://www.nytimes.com/2020/03/27/us/politics/coronavirus-housevoting.html.

Consumer Financial Protection Bureau (CFPB). (2020a). Learn about mortgage relief options. In https://www.consumerfinance.gov/coronavirus/mortgage-andhousing-assistance/mortgage-relief/.

Consumer Financial Protection Bureau (CFPB). (2020b). Protections for renters. In https://www.consumerfinance.gov/coronavirus/mortgage-and-housingassistance/renter-protections/.

Cox, N., Ganong, P., Noel, P., Vavra, J., Wong, A., Farrell, D. \& Greig, F. (2020). Initial impacts of the pandemic on consumer behavior: Evidence from linked income, spending, and savings data. Working Paper. In https://bfi.uchicago.edu/working-paper/initial-impacts-of-the-pandemic-onconsumer-behavior-evidence-from-linked-income-spending-and-savings-data/.

Dallas, R. \& Power, E. (2020). Housing policy and the Covid-19 pandemic: the importance of housing research during this health emergency. International Journal of Housing Policy, 20(2), 177-183. In https://doi.org/10.1080/19491247.2020.1756599. 
DarVoce. (April 9, 2020). Avvocato di Strada: "Emergenza e persone senza dimora, la battaglia continua". In http://www.darvoce.org/blog/news/avvocato-di-stradaemergenza-e-persone-senza-dimora-la-battaglia-continua/.

Davletova, M. I. (2003). Subjective civil law to a dwelling: normative grounds and some problems of legal protection. Kazan: Kazan State University V.I. UlyanovLenin.

Delfinov A. (October 15, 2018). Law criminalizing homeless people comes into force in Hungary. Deutsche Welle. In https://www.dw.com/ru/\%D0\%BA\%D1\%80\%D0\%B8\%D0\%BC\%D0\%B8\%D 0\%BD\%D0\%B0\%D0\%BB\%D0\%B8\%D0\%B7\%D1\%83\%D1\%8E\%D1\%89\% D0\%B8\%D0\%B9-

$\% \mathrm{D} 0 \% \mathrm{~B} 1 \% \mathrm{D} 0 \% \mathrm{~B} 5 \% \mathrm{D} 0 \% \mathrm{~B} 7 \% \mathrm{D} 0 \% \mathrm{~B} 4 \% \mathrm{D} 0 \% \mathrm{BE} \% \mathrm{D} 0 \% \mathrm{BC} \% \mathrm{D} 0 \% \mathrm{BD} \% \mathrm{D} 1 \%$ 8B\%D1\%85-\%D0\%B7\%D0\%B0\%D0\%BA\%D0\%BE\%D0\%BD$\% \mathrm{D} 0 \% \mathrm{~B} 2 \% \mathrm{D} 1 \% 81 \% \mathrm{D} 1 \% 82 \% \mathrm{D} 1 \% 83 \% \mathrm{D} 0 \% \mathrm{BF} \% \mathrm{D} 0 \% \mathrm{~B} 8 \% \mathrm{D} 0 \% \mathrm{BB}-$ $\% \mathrm{D} 0 \% \mathrm{~B} 2-\% \mathrm{D} 1 \% 81 \% \mathrm{D} 0 \% \mathrm{~B} 8 \% \mathrm{D} 0 \% \mathrm{BB} \% \mathrm{D} 1 \% 83-\% \mathrm{D} 0 \% \mathrm{~B} 2-$ $\% \mathrm{D} 0 \% \mathrm{~B} 2 \% \mathrm{D} 0 \% \mathrm{~B} 5 \% \mathrm{D} 0 \% \mathrm{BD} \% \mathrm{D} 0 \% \mathrm{~B} 3 \% \mathrm{D} 1 \% 80 \% \mathrm{D} 0 \% \mathrm{~B} 8 \% \mathrm{D} 0 \% \mathrm{~B} 8 / \mathrm{a}-$ 45899674.

Deutsche Welle. (September 26, 2020). Coronavirus leads to increase in homelessness in the US. In https://p.dw.com/p/3hvZp.

Garg, S. (2020). Hospitalization rates and characteristics of patients hospitalized with laboratory-confirmed coronavirus disease 2019-Covid-NET, 14 states, March 1-30, 2020. Morbidity and mortality weekly report, 69(15), 458-464. DOI: 10.15585/mmwr.mm6915e3.

Goodman, L., Kaul, K. \& Neal, M. (April 2, 2020). The CARES Act Eviction Moratorium Covers All Federally Financed Rentals-That's One in Four US Rental Units. Urban Institute. In https://www.urban.org/urban-wire/cares-act-evictionmoratorium-covers-all-federally-financed-rentals-thats-one-four-us-rentalunits.5.

Hamdi, I. (May 4, 2020). Lima GOR di DKI Tampung 173 Tunawisma. Tempo. In https://metro.tempo.co/read/1338501/lima-gor-di-dki-tampung-173-tunawisma

Hartman, C. (1998). The case for a right to housing. Housing Policy Debate, 9, 223-246. In https://www.innovations.harvard.edu/sites/default/files/hpd_0902_hartman_0.p df.

Hohmann, J. (2013). The Right to Housing: Law, Concepts, Possibilities. New York, USA: Bloomsbury Publishing.

Hulse, C. \& Cochrane, E. (March 26, 2020). As Coronavirus Spread, Largest Stimulus in History United a Polarized Senate. The New York Times. In https://www.nytimes.com/2020/03/26/us/coronavirus-senate-stimuluspackage.html

Italy. (April 25, 2020). Decreto \#IoRestoaCasa, domande frequenti sulle misure adottate dal Governo. In http://www.governo.it/it/faq-iorestoacasa. 
Jordà, Ò., Singh, S. \& Taylor, A. (2020). Longer-run economic consequences of pandemics. Cambridge, MA: National Bureau of Economic Research. In https://www.nber.org/papers/w26934.pdf.

Kachalova, I.V. (2006). Ownership and other property rights of citizens to living quarters. Moscow: Lomonosov Moscow State University. In http://89.208.148.166/diss/cont/208174.html.

Kenya. (2011). Constitutional Petition $\mathrm{n}^{\circ} 2$. In https://www.escrnet.org/caselaw/2012/constitutional-petition-no-2-2011-garissa.

Kompas. (May 3, 2020). DKI Siapkan GOR untuk Warga Telantar yang Tak Mampu Bayar Kontrakan. In https://megapolitan.kompas.com/read/2020/05/03/13195981/dki-siapkan-goruntuk-warga-telantar-yang-tak-mampu-bayar-kontrakan.

Kravchenko, M. V. \& Cheberyak, Yu. P. (2017). Realization of the right of citizens to housing in modern conditions: public administration aspect. Public administration: theory and practice, 2(18), 1-11. In http://www.dridu.dp.ua/zbirnik/2017-02(18)/9.pdf.

Leifheit, K., Linton, S., Raifman, J., Schwartz, G., Benfer, E., Zimmerman, F. \& Pollack, C. (2020). Expiring Eviction Moratoriums and Covid-19 Incidence and Mortality. In https://ssrn.com/abstract=3739576.

Lima N., de Souza R., Feitosa P., Moreira J., da Silva C. \& Neto M. (2020). People experiencing homelessness: Their potential exposure to Covid-19. Psychiatry Res. DOI: 10.1016/j.psychres.2020.112945. In https://pubmed.ncbi.nlm.nih.gov/32302813/.

Liu, S. \& Su, Y. (2020). The Impact of the Covid-19 Pandemic on the Demand for Density: Evidence from the U.S. Housing Market. Federal Reserve Bank of Dallas, 1, 1-26. In https://www.dallasfed.org//media/documents/research/papers/2020/wp2024.pdf.

Mas, A. \& Pallais, A. (2020). Alternative work arrangements. Cambridge, MA: National Bureau of Economic Research. In http://www.nber.org/papers/w26605.

McCarty, M. \& Carpenter, D. (April 7, 2020). CARES Act Eviction Moratorium (Report). Congressional Research Service. In https://crsreports.congress.gov/product/pdf/IN/IN11320.

National Police of Ukraine. (August 7, 2020). In six months, police have opened about 900 criminal proceedings for domestic violence. In https://www.kmu.gov.ua/news/za-piv-roku-policiya-vidkrila-blizko-900kriminalnih-provadzhen-za-faktom-domashnogo-nasilstva-oleksandr-facevich.

Official California State Government Website. (2020). Housing and HomelessnessCoronavirus Covid-19 Response. In https://covid19.ca.gov/housing-andhomelessness/.

Pchelintseva, L. M. (2004). Research problems of the nature and content of the constitutional right to housing. Constitutional and Municipal Law, 2, 11-14. 
Perri, M., Dosani, N. \& Hwang, S. (2020). Covid-19 and people experiencing homelessness: challenges and mitigation strategies. Canadian Medical Association Journal, 192(26), 716-719. In https://doi.org/10.1503/cmaj.200834.

Peterman, A., Potts, A., O’Donnell, M., Thompson, K., Shah, N., Oertelt-Prigione, S. \& van Gelder, N. (2020). Pandemics and violence against women and children. Center for Global Development, 528, 1-45. In https://www.cgdev.org/sites/default/files/pandemics-and-vawg-april2.pdf.

Pramuk, J. (March 25, 2020). Senate passes \$2 trillion coronavirus stimulus package, sending it to the House. CNBC. In https://www.cnbc.com/2020/03/25/senatepasses-2-trillion-coronavirus-stimulus-package.html.

Roshchyna, V. (December 7, 2020). This year, the number of complaints to the police about domestic violence has significantly increased in Ukraine. Hromadske. In https://hromadske.ua/posts/cogorich-v-ukrayini-kilkist-zayav-do-policiyicherez-domashnye-nasilstvo-zbilshilas-majzhe-vdvichi.

Russian Government official website. (2020). Measures of the Government of the Russian Federation to combat coronavirus infection and support the economy. In http://government.ru/support_measures/.

Sedugin, P. I. (2003). Housing law. Moscow: Norma.

Senate and House of Representatives of the USA. (2020). Coronavirus Aid, Relief, and Economic Security Act. In https://www.govinfo.gov/content/pkg/PLAW116publ136/pdf/PLAW-116publ136.pdf.

Skripko, V. R. (2002). The constitutional right of citizens of the Russian Federation to housing. State and law, 12, 31-39. In https://izvuz_on.pnzgu.ru/files/izvuz_on.pnzgu.ru/1411.pdf.

Snell, K. (March 26, 2020). What's Inside The Senate's \$2 Trillion Coronavirus Aid Package. NPR. In https://www.npr.org/2020/03/26/821457551/whats-insidethe-senate-s-2-trillion-coronavirus-aid-package.

Sotnikova, L. V. (2006). The Right to Housing: History and Today. Bulletin of South Ural State University, 3, 163-167. In https://cyberleninka.ru/article/n/pravo-nazhilische-istoriya-i-segodnyashniy-den.

South Africa. Constitutional Court. (2000). Government of the Republic of South Africa and Others $v$ Grootboom and Others (CCT11/00) [2000] ZACC 19; 2001 (1) SA 46; 2000 (11) BCLR 1169 (4 October 2000). In http://www.saflii.org/za/cases/ZACC/2000/19.html.

Taub, A. (April 6, 2020). A New Covid-19 Crisis: Domestic Abuse Rises Worldwide. The New York Times. In https:/www.nytimes.com/2020/04/06/world/coronavirusdomestic-violence.html.

Taylor, A., Fram, A., Kellman, L. \& Superville, D. (March 28, 2020). Trump signs \$2.2T stimulus after swift congressional votes. Associated Press. In https://apnews.com/2099a53bb8adf2def7ee7329ea322f9d. 
Tenant, Homeowner, and Small Landlord Relief and Stabilization Act of 2020. In https://www.gov.ca.gov/wp-content/uploads/2020/08/Factsheet-TenantHomeowner-and-Small-Landlord-Relief-and-Stabilization-Act-of-2020.pdf.

Todd, M. (November 2, 2020). Ask an Expert: What is Covid-19's impact on the homelessness crisis? Vanderbilt University. In https://news.vanderbilt.edu/2020/11/02/ask-an-expert-what-is-covid-19simpact-on-the-homelessness-crisis/.

Townsend, M. (April 12, 2020). Revealed: surge in domestic violence during Covid-19 crisis. The Guardian. In https://www.theguardian.com/society/2020/apr/12/domestic-violence-surgesseven-hundred-per-cent-uk-coronavirus.

Ukrainian Soviet Socialist Republic. (1983). Housing Code. In https://zakon.rada.gov.ua/laws/show/5464-10\#Text.

Ukrinform. (December 8, 2020). There are no shelters for victims of domestic violence in seven regions. In https://www.ukrinform.ua/rubric-society/3150523-u-semiregionah-nemae-pritulkiv-dla-zertv-domasnogo-nasilstva-denisova.html.

United Nations Human Rights Council (UN HRC). (December 30, 2015). Special Rapporteur on adequate housing as a component of the right to an adequate standard of living, and on the right to non-discrimination in this context: Report A/HRC/31/54. In https://undocs.org/en/A/HRC/31/54.

United Nations. (1951). Convention relating to the Status of Refugees. In https://www.ohchr.org/en/professionalinterest/pages/statusofrefugees.aspx.

United Nations. (1965). Convention on the Elimination of all Forms of Racial Discrimination. In https://www.ohchr.org/en/professionalinterest/pages/cerd.aspx.

United Nations. (1966). International Covenant on Civil and Political Rights (ICCPR). In https://www.ohchr.org/EN/ProfessionalInterest/Pages/CCPR.aspx.

United Nations. (1966). International Covenant on Economic, Social and Cultural Rights. In https://www.ohchr.org/en/professionalinterest/pages/cescr.aspx.

United Nations. (2015). Human Settlements Program (UN-Habitat). In https://www.un.org/ruleoflaw/un-and-the-rule-of-law/united-nations-humansettlements-programme/.

United Nations. (2019). Special Rapporteur on Adequate Housing. In https://www.ohchr.org/en/issues/housing/pages/housingindex.aspx .

United States Department of Housing and Urban Development (US DHUD). (May 1, 2020). HOME Investment Partnerships Program FAQs - Covid-19 \& CARES Act (PDF): Report. In https://www.hud.gov/sites/dfiles/CPD/documents/HOME-FAQs-Covid-19.pdf.

Universal Declaration of Human Rights. (1948). In https://zakon.rada.gov.ua/laws/show/995_015.

Usher, K., Bhullar, N., Durkin, J., Gyamfi, N. \& Jackson, D. (2020). Family violence and COVID-19: Increased vulnerability and reduced options for support. 
International Journal of Mental Health Nursing, 29, 549-552. In https://onlinelibrary.wiley.com/doi/pdf/10.1111/inm.12735.

Van Gelder, N., Peterman, A., Potts, A., O’Donnell, M., Thompson, K., Shah, N. \& Oertelt-Prigione, S. (2020). Covid-19: Reducing the risk of infection might increase the risk of intimate partner violence. EClinicalMedicine, 21, 1-2. In https://www.thelancet.com/journals/eclinm/article/PIIS2589-5370(20)300924/fulltext.

Veschunova, E. V. (2017). The essence and content of the constitutional right of citizens to housing. Electronic scientific journal "Science. Society. State”, 3(19), 1-5. In https:.cyberleninka.ru/article/v/suschnost-i-soderzhanie-kontitutsionnogoprava-grazhdan-na-zhilische.

Wheelock, D. (2020). Comparing the Covid-19 Recession with the Great Depression. Economic Synopses, 39, 1-4. In https://doi.org/10.20955/es.2020.39.

Wire, S. (March 25, 2020). Senate passes \$2-trillion economic stimulus package. The Los Angeles Times. In https://www.latimes.com/politics/story/2020-03-25/votesenate-on-2-trillion-economic-stimulus-package-coronavirus.

World Health Organization (WHO). (March 11, 2020). Coronavirus disease 2019 (Covid19): Report 51. In https://www.who.int/docs/defaultsource/coronaviruse/situation-reports/20200311-sitrep-51-Covid-19.pdf. 